\title{
Developing Civil Servants' Affective Commitment to Share Knowledge: A Case of Public Organization Cost Reduction
}

\author{
Mohamad Hisyam Selamat ${ }^{1}$, Rafeah Mat Saad ${ }^{2}$, Rusdi @ Indra Zuhdi Murat ${ }^{3} \&$ Foo Kok Soon ${ }^{4}$ \\ ${ }^{1}$ Faculty of Business, Accounting \& Management, SEGi University, Petaling Jaya, Malaysia \\ ${ }^{2}$ School of Accountancy, Universiti Utara Malaysia, Sintok, Malaysia \\ ${ }^{3}$ School of Quantitative Sciences, Universiti Utara Malaysia, Sintok, Malaysia \\ ${ }^{4}$ Institute of Graduate Studies, SEGi University, Petaling Jaya, Malaysia \\ Correspondence: Mohamad Hisyam Selamat, Faculty of Business, Accounting \& Management, SEGi University, \\ 47810 Petaling Jaya, Selangor, Malaysia. Tel: 603-6145-5888. E-mail: mohdhisyam@segi.edu.my
}

Received: October 6, 2016

doi:10.5539/ijbm.v12n2p160
Accepted: January 20, 2017

Online Published: January 26, 2017

URL: http://dx.doi.org/10.5539/ijbm.v12n2p160

\begin{abstract}
The present study is designed to propose values for developing civil servants' affective commitment to share knowledge in the workplace. The proposed values are faith, sincerity, trusting belief, trusting intention and emotional trust. The researchers have applied cross-sectional survey research to validate the framework. It is found that faith and sincerity influenced the development of civil servants' affective commitment to share knowledge in the workplace significantly. The practical implications are the discovery of theoretical, personal, and workplace practical best practices for the establishment of strategies to reduce operational costs in the public organization.
\end{abstract}

Keywords: internal values, affective commitment, knowledge sharing, cost reduction, public organization

\section{Introduction}

One of the measurements in determining fiscal strength of a country is deficit rate (Blanchard, 2011; Omar Othman et al., 2007). They stated that there are two ways of reducing budget deficit which are increasing revenue and reducing expenditure. However, the focus of this research is on reducing expenditure. As a big chunk of tax revenues of any country including Malaysia is contributed by corporate tax, the area of increasing revenue is quite complicated as it is depending on global economy, which is always fluctuating. Cost reduction is normally an internal matter of government agencies or departments, which can be monitored and controlled by the director general. Thus the study on this phenomenon is much more feasible and practical.

Cost reduction field of study is closely related to organizational effectiveness and efficiency. However, most of the studies on public sector relate effectiveness and efficiency to issues such as quality service, public satisfaction, managerial accountability and public stewardship. In other words, people expect high quality of service and good living environment (high income and low cost of living) from the government. This poses a big challenge to the government as to whether they want to be a populace government, which leads to worst fiscal deficit, or growth-friendly government. To sustain prosperity, this research argues that the government should be more innovative in reducing expenditure, without compromising on the concepts of people caring and steady economic growth. This could also lead to the perception that the current government is working with full integrity.

To reduce public expenditure, however, civil servants must have affective commitment to share knowledge or ideas on what is the best strategy to reduce expenditure (Meyer \& Allen, 1991). Affective commitment refers to the emotional or psychological connection of an individual to identify and participate in the organization (Meyer \& Allen, 1991). Knowledge is the basis for the generation of ideas and in turn innovative action, reaction and reflection (Selamat \& Choudrie, 2007). However it is the property of human being (Churchman, 1971; Tsoukas \& Vladimirou, 2001; Beveren, 2002; Tsoukas, 2002). Thus for civil servants to share it they must have emotional or psychological connection to public organizations. In short, the objective of this research is to examine values that can develop civil servants' emotional and psychological connection to public organizations so that they are more willing to share knowledge or ideas on what is the best strategy to reduce public organization operational 
cost. To assist in the process of developing civil servants' affective commitment to actively share knowledge, this research proposes the elements of faith, sincerity, trusting belief, trusting intention and emotional trust. All these values are embedded in the conceptual framework.

The paper is organized as follows. Next section presents a theoretical justification for every element in the conceptual framework. Section 3 discusses research approach adopted to validate the proposed factors. Finally, a conclusion is presented in the concluding section.

\section{Theoretical Overview}

For the theoretical understanding of public organization cost reduction we posit that public organization cost reduction is based on the concepts of individual affective commitment and knowledge sharing. In the following sections a discussion of affective commitment and knowledge sharing is offered.

\subsection{Public Sector Financial Management}

The most important activity in public sector financial management is budgeting. There are three types of government budget, namely, deficit budget, surplus budget and balanced budget. Amongst the three types of government budget, deficit budget is the one that is usually creating negative perception amongst people and business community (Alessi, 2012; Blanchard, 2011). This is because it shows government incapability in controlling expenditures and increasing revenues. The failure to increase revenues is also related to the failure to create business activities through public projects such as infrastructure, highway, hospital, school and others. Thus managing deficit rate for the sake of economic growth is critical to every country including Malaysia.

Due to negative impact of high deficit rate on the financial system and fiscal strength, a country that has high deficit rate is usually given low rating by the credit rating agencies such as Standard \& Poor, Moody's, and Fitch Group (Alessi, 2012). The country that get poor rating will be imposed higher interest rate by the international financial institutions including companies incorporated in that country. This will affect badly domestic direct investment in the country (Blanchard, 2011). Foreign direct investment will be also badly affected because foreign investors are reluctant to invest in a country that is not financially and politically stable (Blanchard, 2011). Low investment will reduce economic growth and in turn increase unemployment rate in the country (Blanchard, 2011). This is the scenario that every government in the world, including Malaysia, is trying to avoid. Thus obtaining good ratings through balanced budget or lower deficit rate is a must for every country.

There are two ways of reducing budget deficit which are increasing revenue and reducing expenditure (Blanchard, 2011; Omar Othman et al., 2007). However, the focus of this research is on reducing expenditure. As $80 \%$ of Malaysian tax revenues contributed by corporate tax, the area of increasing revenue is quite complicated as it is depending on global economy, which is always fluctuating. Cost reduction is normally an internal matter of ministries, departments and agencies, which can be monitored and controlled by the government (Omar Othman et al., 2007). Thus the study on this phenomenon is much more feasible and practical and in tandem with the aspiration of many governments in the world.

\subsection{Public Organization Cost Reduction and Tacit Knowledge}

The reduction of government expenditure is always looked at the organizational perspective. In this case, the ministries, departments and agencies have to cut several non-critical expenses and postpone non-critical projects. This study, however, will look at the individual perspective because it is quite difficult to get access data on public expenditure from the organizational perspective.

To reduce public expenditure, however, civil servants must have affective commitment to share knowledge or ideas on what is the best strategy to reduce expenditure. As knowledge is the property of human being (Tsoukas, 2002; Beveren, 2002; Tsoukas \& Vladimirou, 2000; Churchman, 1971), civil servants need a high level of emotional and psychological connection to public organization before they could participate in the process of identifying the strategies to implement low-cost yet high-impact public services.

Affective commitment is required in in the process of identifying the strategies to implement low-cost yet high-impact public services because it is hard to sustain the process of transforming tacit knowledge to tangible knowledge (Henttonen, Kianto, \& Ritala, 2016; Amayah, 2013; Selamat \& Choudrie, 2007; Tsoukas, 2002; Nonaka \& Takeuchi, 1995). This is because subjective nature of tacit knowledge decreases the ability of an individual to articulate his or her views. Haldin-Herrgard (2000) stated that there are four factors that lead to the difficulty in expressing and sharing tacit knowledge, namely, perception, language, time, value and distance. In the case of perception, the characteristics of unconsciousness result in the people become unaware of the full range of their knowledge and potential (Polanyi, 1958; 1967). The difficulty with language is related to the characteristic of tacit knowledge, which exists in a non-verbal form (Haldin-Herrgard, 2000). Time also becomes 
a hurdle in the process of externalizing and sharing of tacit knowledge. This is because, during the formation of knowledge in the mindset, tacit knowledge internalization needs a longer period of time. The difficulty in value results from the nature of tacit knowledge whereby not all knowledge that resides in an individual's mindset have value that give them merit to be externalized and shared (Haldin-Herrgard, 2000). Distance factor also contributes towards the difficulty in tacit knowledge externalization and sharing. This is because tacit knowledge can be externalized and shared actively if the involved individuals meet each other and then having face-to-face interaction (Holtshouse, 1998; Leonard \& Sensiper, 1998).

Other inhibitors that could stop civil servants from sharing ideas on what is the best strategy to reduce expenditure are such as fear, low confidence level, reluctance to do it, and confusion due to negative sentiments (Henttonen et al., 2016; Amayah, 2013). This phenomenon occurs in an organization due to the difference in superiority and seniority. Another factor that separate civil servants in the workplace is different nature of social background (Amayah, 2013). This is due to the nature of human beings being attracted to a group that has similar backgrounds such as academic qualification, age, race, gender and others (Henttonen et al., 2016; Amayah, 2013; Ali, 1998).

Another possible factor that could discourage communication between civil servants is the acceptance of others towards their ideas (Amayah, 2013; Selamat \& Choudrie, 2007; Bennett, 1998). Some civil servants feel that their opinions will not be accepted due to their positions within the organization or that they do not have enough of an influence to provide a significant contribution to the organization (Amayah, 2013; Selamat \& Choudrie, 2007; Bennett, 1998). This apprehension forces them to keep their knowledge or skills in their own mindset and results in the individuals becoming passive in formal meetings and undertaking sole tasks.

To recapitulate, the failure to overcome the above knowledge sharing issue could lead to ineffective and inefficient public organization daily operation (Henttonen et al., 2016; Amayah, 2013). In turn, the increase in public organization operational costs is inevitable. To face such phenomenon, this research argues that civil servants need to be equipped with positive value of faith, sincerity, trusting belief, trusting intention and emotional trust. Civil servants who are not embedded with these values tend to be passive in terms of commitment to share knowledge or ideas on what is the best strategy to reduce expenditure.

\subsection{Developing Civil Servants' Affective Commitment}

As stated above, affective commitment refers to the emotional or psychological connection of an individual to identify and participate in the organization (Meyer \& Allen, 1991). Affective commitment construct is developed based on Meyer and Allen's (1991) organizational commitment model. The focus of this research is on what values that can develop civil servants' self-commitment (individual commitment) and not what public organization should do to increase civil servants' commitment in public organization cost reduction (organizational commitment). In other words, this research extends the use of Meyer and Allen's (1991) model. This research proposes five values that could develop civil servants' affective commitment to share knowledge or ideas on what is the best strategy to reduce expenditure, namely, faith, sincerity, trusting belief, trusting intention and emotional trust.

\subsubsection{Faith}

Faith is a great trust or confidence in something or someone (Cambridge International Dictionary of English, 1995). Its position is much higher than trust or confidence. Having faith in knowledge sharing and its role in sustaining public organization enables civil servants to have strong emotional or psychological connection to public organization. In turn, motivates them to share ideas and opinions in the meeting in relation to strategies to reduce operational costs.

Pedler, Burgoyne and Boydell (1994), Butcher, Harvey and Atkinson (1997) and Harvey and Butcher (1998) found that there is a significant relationship between faith in organization and organizational performance. On the other hand, Selamat and Choudrie (2007) and Abdul Wahab, Selamat and Saad (2013) found a significant relationship between faith in organization and the willingness to externalize and share knowledge and skills within the organization. Haldin-Herrgard (2000) further supported this axiom by saying that lack of faith prevents staff members from externalizing and sharing their tacit knowledge. Thus it could be said that if civil servants have faith that Malaysia need to reduce expenditure in order to achieve low deficit rate and in turn obtain good international ratings for positive economic prospect they will become more receptive towards cost reduction policy. This emotion in turn motivates them to participate actively in the brainstorming session that aims to determine the best strategy to reduce office expenditure - involves active knowledge sharing. All these scenarios lead to the following hypothesis: 
H1: There is a relationship between faith and affective commitment to share knowledge on what is the best strategy to reduce expenditure amongst civil servants

\subsubsection{Sincerity}

Sincerity is the most important value that should be instilled in the workplace including public organizations. Every civil servant must have a feeling that he or she works for the sake of the people and for fulfilling his or her responsibility to the country. The important role of sincerity in developing effective individuals has been stressed by Schroder (1989). This is further supported by Selamat et al. (2015), Selamat and Choudrie (2007), Abdullah and Selamat (2007) and Abdul Wahab, Selamat and Saad (2012). They obtained an effective role of sincerity in motivating staff members to participate in learning environment. The main reason why an organization recruits people is to assist management in achieving its goals. Thus every recruited staff has to bear in his or her mind in the workplace that "we must perform organizational tasks sincerely." The value of sincerity also gives staff members a strength to ignore any negative sentiment to the management, that is created through gossip and slander (Schroder, 1989; Selamat \& Choudrie, 2007). Thus it could be said that if civil servants are sincere in their job and country they will support policies that aim to protect country's sovereignty including cost reduction policy. This emotion in turn motivates them to participate actively in the brainstorming session that aims to determine the best strategy to reduce office expenditure - involves active knowledge sharing. All these scenarios lead to the following hypothesis:

$\mathrm{H} 2$ : There is a relationship between sincerity and affective commitment to share knowledge on what is the best strategy to reduce expenditure amongst civil servants

\subsubsection{Trusting Belief}

According to Mayer et al. (1995), trusting belief consists of three attributes: (1) competence belief that means staff members have confidence that the organization has the necessary skills to perform the job; (2) benevolence belief that reflects staff members' confidence that the organization has a positive orientation toward them and not only consider their profit goals; and (3) integrity belief that reflects staff members' confidence that the organization following a set of moral principles or professional standards that guide user-organization relationships. These trusting beliefs are related, yet distinct.

Beatty et al. (2011), McKnight et al. (2002) and McKnight et al. (1998) examined the above three attributes of trusting belief from the perspective of e-commerce transaction and found significant relationships between them. Tangaraja, Mohd Rasdi, Ismail and Abu Samah (2015) and Mohammed Fathi, Eze and Guan (2011) examined trust from the perspective of public sector performance and found significant relationship between them. Thus it is argued that if civil servants have beliefs that reducing public sector expenditure is critical in reducing national deficit rate and in turn attaining good international ratings they will be more receptive towards cost reduction policy. This represents their positive emotional and psychological connection to the organization. Being equipped with this value makes them more supportive when are asked to give ideas on how to reduce office expenditure - involves active knowledge sharing. Thus the following research hypothesis is proposed:

H3: There is a relationship between trusting belief and affective commitment to share knowledge on what is the best strategy to reduce expenditure amongst civil servants

\subsubsection{Trusting Intention}

Trusting intention is defined as the intention to engage with the organizations that staff members feel secure with (McKnight et al., 2002). It can also be described as "to what extent staff members are willing to involve in risky situation" (Kim et al., 2004, p. 105). Schlosser et al. (2006) uncovered that online buyers are willing to provide their personal information such as credit card number, address and contact number (which could ruin their life) to the firms if they trust them. Tangaraja et al. (2015) and Mohammed Fathi et al. (2011) stated that there is a significant relationship between trust and civil servants' performance. Thus it could be said that civil servants are expected to be more receptive towards cost reduction policy if they are aware that bad international ratings could jeopardize future Malaysian economic growth. This represents their positive emotional and psychological connection to the organization. Being equipped with this value makes them more supportive when are asked to give ideas on how to reduce office expenditure - involves active knowledge sharing. Thus this study proposes the following hypothesis:

H4: There is a relationship between trusting intention and affective commitment to share knowledge on what is the best strategy to reduce expenditure amongst civil servants

\subsubsection{Emotional Trust}


Emotional trust refers to feeling toward the behavior of relying on the other side (trustees) (Komiak \& Benbasat, 2004). Xie and Peng (2011) stated that emotional trust reinforces relationship between organizations and staff members. Beatty et al. (2011) and Min and Lee (2009) stated that emotional trust and cognitive trust complement each other perfectly in influencing an individual's decision on whether to trust or not the other party. In e-commerce transaction, the buyers tend to emotionally response to product or seller which making the decision becomes less cognitively dominated (Komiak \& Benbasat, 2006). Tangaraja et al. (2015) and Mohammed Fathi et al. (2011) uncovered that there is a strong relationship between social trust and public sector performance. Thus it could be said that if civil servants have an emotion that Malaysia must achieve low deficit rate in order to obtain good ratings and in turn positive economic growth, they will become more receptive towards cost reduction policy. This emotion in turn motivates them to participate actively in the brainstorming session that aims to determine the best strategy to reduce office expenditure - involves active knowledge sharing. All these scenarios lead to the following hypothesis:

H4: There is a relationship between emotional trust and affective commitment to share knowledge on what is the best strategy to reduce expenditure amongst civil servants

\section{Research Methodology}

Data of this study were gathered through a survey approach. Survey is considered to be the favoured tool for data collection amongst quantitative researchers (Fowler, 2009). In addition, it is one of the most common data collection methods for examining the participation in cost reduction commitment and knowledge sharing commitment (Selamat et al., 2015; Jain \& Jeppesen, 2013; Amayah, 2013). Survey research suits the unit of analysis of this study, which are civil servants in the Malaysian public organizations. Dwivedi (2005) suggested that when the unit of analysis is individual rather than organization, survey approach is more preferable than other approaches such as case study. This study utilized stratified random sampling as a sampling technique. Stratified random sampling, as its name implies, involves a process of stratification or segregation, followed by random selection of subjects from each stratum (ministries) (Sekaran, 2003; Fowler, 2009; Babin \& Griffin, 2010). A total of 400 civil servants in federal government ministries across Malaysia were randomly selected. The questionnaires were distributed by liaison officers (most of them are auditors of the Auditor's General Department). They were selected because they have the authority to communicate with the respondents. Multiple regression analysis was used to test the relationship between independent variables and dependent variable.

\section{Research Findings}

Out of 400 distributed questionnaires, 130 were returned. This resulted in a response rate of $32.5 \%$. As suggested by Sekaran (2003), a response rate of $30 \%$ is considered adequate for mail survey research. Based on this suggestion, the response rate of this study $(32.5 \%)$ was above the recommended rate. In turn, the findings of this research can be generalized to the population.

\subsection{Profile of Respondents}

The frequency and percentage of each demographic profile are illustrated in Table 1. The reported demographic profiles include gender, age and number of years working in the current university.

Table 1. Background of the respondents $(\mathrm{N}=130)$

\begin{tabular}{lll}
\hline & Frequency & Percentage \\
\hline Gender & & \\
Male & 56 & 43.1 \\
Female & 74 & 56.9 \\
Age (years) & & 3.8 \\
$21-30$ & 5 & 45.4 \\
$31-40$ & 59 & 30.8 \\
$41-50$ & 40 & 20.0 \\
$51-60$ & 26 & - \\
$>60$ & - & \\
Length of Service & & 23.1 \\
$<5$ & 30 & 30.8 \\
$<10$ & 40 & 12.3 \\
$<15$ & 16 & 15.4 \\
$<20$ & 20 & 18.5 \\
$>21$ & 24 & \\
\hline
\end{tabular}


In this research, gender distribution was slightly higher for female. Out of 130 respondents, 56 (43.1\%) respondents are male and $74(56.9 \%)$ respondents are female. The largest group of respondents $(\mathrm{N}=59,45.4 \%)$ reported that they were in the "31-40" age group. The second largest group consisted of respondents with age "41-50" ( $\mathrm{N}=40,30.8 \%)$, third largest group consisted of respondents with age " $51-60 "(\mathrm{~N}=26,20.0 \%)$ and fourth largest group consisted of respondents with age " $21-30$ " $(\mathrm{N}=5,3.8 \%)$. There was no respondent in "Over 60 " age group.

The largest group of respondents $(\mathrm{N}=40,30.8 \%)$ indicated that they have worked at the current university " 10 years or less". The second largest group of respondents $(\mathrm{N}=30,23.1 \%)$ reported that they have worked at the current organization " 5 years or less). This is followed by "over 21 years" category $(\mathrm{N}=24,18.5 \%)$.

\subsection{Reliability Analysis}

To test the reliability of the research instrument, as suggested by Sekaran (2003), this study utilized internal consistency method which is measured by Cronbach's alpha. The coefficient for the Cronbach's alpha is expressed between 0 and 1.00. The results of the Cronbach's alpha values of the variables are as illustrated in Table 2.

Table 2. Reliability coefficients for variables $(\mathrm{N}=130)$

\begin{tabular}{lcc}
\hline Variable & N of Item & Cronbach Alpha \\
\hline Faith & 6 & 0.858 \\
Sincerity & 6 & 0.937 \\
Trusting belief & 20 & 0.918 \\
Trusting intention & 9 & 0.838 \\
Emotional trust & 8 & 0.668 \\
Affective commitment to share knowledge & 6 & 0.775 \\
\hline
\end{tabular}

As shown in Table 2, the Cronbach's alpha values for variables varied between 0.668 (emotional trust) and 0.937 (sincerity). Two variables possessed Cronbach's alpha values above 0.90 (sincerity and trusting belief), two between 0.80 and 0.90 (faith and trusting intention), one between 0.70 and 0.80 (affective commitment to share knowledge) and only one below than 0.70 (emotional trust). In other words, none of the study variables demonstrated below the minimum reliability level of 0.60 (Hair, Black, Babin, Anderson, \& Tatham, 2006). Thus the internal consistency of the measures used in this study was considered acceptable (Churchill, 1979; Sekaran, 2003).

\subsection{Multiple Regression Analysis}

Date refinement was undertaken prior to multiple regression analysis. It was divided into data screening and data testing, which aim to fulfill the multivariate assumptions (Hair et al., 2006). Data screening consists of three tests which are missing data, response bias and outliers identification. On the other hand, data testing consists of linearity, normality, homoscedasticity and multicollinearity tests. The criteria for all these tests were met in this study.

To test this research hypotheses multiple regression analysis was utilized and its findings are illustrated in Tables 3. As illustrated in Table 3, the value of adjusted $\mathrm{R}$ square is 0.661 . This shows that all independent variables (faith, sincerity, trusting belief, trusting intention and emotional trust) explain $66.1 \%$ variance in the affective commitment to share knowledge or ideas on what is the best strategy to reduce expenditure amongst civil servants.

Table 3. Effect of independent variables on affective commitment to share knowledge

\begin{tabular}{lccc}
\hline & B & t & Sig. \\
\hline Faith & .270 & 3.176 & .002 \\
Sincerity & .682 & 6.667 & .000 \\
Trusting Belief & .168 & 1.813 & .072 \\
Trusting Intention & -.121 & -1.064 & .290 \\
Emotional Trust & .074 & .883 & .379 \\
$\mathrm{R}^{2}$ & 0.661 & & \\
F & 23.199 & & \\
Sig. & 0.000 & & \\
\hline
\end{tabular}


Table 3 also illustrates that only two variables were found to have significant effect on affective commitment to share knowledge or ideas on what is the best strategy to reduce expenditure amongst civil servants. They were faith $(\mathrm{B}=0.270, \mathrm{t}=3.176, \mathrm{p}<0.01)$ and sincerity $(\mathrm{B}=0.682, \mathrm{t}=6.667, \mathrm{p}<0.05)$. Thus $\mathrm{H} 1$ and $\mathrm{H} 2$ were accepted.

\subsection{Discussion}

This study found that faith was positively and significantly influenced civil servants' affective commitment to share knowledge or ideas on what is the best strategy to reduce office expenditure. This finding is consistent with the previous studies such as Selamat et al. (2015), Jain and Jeppesen (2013) and Amayah (2013). From this result it could be said that civil servants that have low faith or do not believe in cost reduction policy will be hesitate to share ideas on what is the best strategy to reduce office expenditure. This is because reducing office expenditure means that unnecessary activities such as travelling, training and entertainment need to be cancelled. In turn, civil servants become pessimistic to cost reduction policy and in turn reluctant to share ideas on what is the best strategy to reduce expenditure. Thus civil servants must be embedded with the belief that cost reduction policy is capable of improving national fiscal strength and in turn international ratings. This belief in turn will motivate them to actively share ideas on what is the best strategy to reduce expenditure in the workplace.

This study also found that sincerity was positively and significantly influenced civil servants' affective commitment to share knowledge or ideas on what is the best strategy to reduce office expenditure. This finding is consistent with the previous studies such as Selamat and Choudrie (2007), Abdullah and Selamat (2007) and Abdul Wahab et al. (2012). In other words, sincerity was perceived by civil servants as the influencing factor to participate or not to participate in the discussion on cost reduction policy implementation. The probable explanation could be the norm that sincerity is the most important value in every human endeavor and reducing expenditure is not exceptional. This is because, based on the norm of reciprocity, when public organization offers job and salary to sincere civil servants, they may feel obligated to reciprocate and become more committed to organizational plans and goals.

Surprisingly, this study found that emotional trust, trusting belief and trusting intention were not positively and significantly influenced civil servants' affective commitment to share knowledge or ideas on what is the best strategy to reduce office expenditure. Implicit in this finding is that civil servants do not trust the management and government when they reduce office expenditure. This scenario might be influenced by political perception of civil servants to ruling party in the democratic country like Malaysia. In the internet era, it cannot be stopped because of easiness to get access to websites that spread negative perception on any government policy including cost reduction policy. From the working perspective, this study contends that civil servants must work professionally whereby they must implement any policies that are implemented by the current government. They should not let political preference influence their performance and responsibility in the workplace. In short, to develop civil servants' affective commitment to participate in the process of identifying strategy to reduce office expenditure the elements of faith and sincerity need to be given more attention by the public organizations.

\section{Conclusion}

The objective of this study was to determine whether individual affective commitment (faith, sincerity, trusting belief, trusting intention and emotional trust) develop civil servants' affective commitment to share knowledge or ideas on what is the best strategy to reduce office expenditure. From the findings, the proposed conceptual framework was substantially validated. The findings showed that the effect of faith and sincerity on the commitment to share knowledge or ideas on what is the best strategy to reduce office expenditure was significant.

Although this study have contributed to public financial management area, several limitations have to be considered. First, the context of this study is limited to civil servants. For future research it is suggested that a comparison is made between civil servants and practitioners. Second, this research conceptual framework was tested and examined from the Malaysian perspective. Thus obtaining feedback from the public sector in other countries is necessary. Third, this research adopted cross-sectional survey for data collection. To gain a broad view on the issues related to public organization cost reduction and knowledge sharing, a longitudinal study is advised. Last but not least, unit of analysis of this study was an individual whereby civil servants were selected as the respondents. To gain more variance in the analysis, obtaining feedback from all individuals working in the public sector is strongly recommended.

\section{References}

Abdul Wahab, M. S., Selamat, M. H., \& Saad, R. A. (2012). Work environment inhibitors to informal workplace learning activities amongst accountants: A Malaysian case study. Paper presented at the first UUMCOB 
Qualitative Research Conference, Kuala Lumpur (4-7 November 2012).

Abdul Wahab, M. S., Selamat, M. H., \& Saad, R. A. J. (2013). The importance of continuing professional education activities amongst Malaysian accountants in public accounting firms. Paper presented at the fourteenth Asian Academic Accounting Association, Penang.

Abdullah, A., \& Selamat, M. H. (2007). Preparing individuals for establishing learning-based management accounting and control system. Paper presented at the Accounting Studies International Conference, Kuala Lumpur (30-31 October 2007).

Amayah, A. T. (2013). Determinants of knowledge sharing in a public sector organization. Journal of Knowledge Management, 17(3), 454-471. http://dx.doi.org/10.1108/JKM-11-2012-0369

Armstrong-Stassen, M. (2008). Organisational practices and post-retirement employment experience of older workers. Human Resource Management Journal, 18, 36-53.

Ashton, D. N. (2004). The impact of organizational structures and practices on learning in the workplace. International Journal of Training and Development, 8(2), 43-53.

Babin, Z., \& Griffin, C. (2010). Business research method (8th ed.). Ohio: South-Western/Cengage Learning.

Barham, K., \& Rassam, C. (1989). Shaping the corporate future. London: Ashridge Management Research Group, Unwin Hyman.

Barr, R., \& Tagg, J. (1995, November/December). From teaching to learning: A new paradigm for undergraduate education. Change, 27(6), 13-25.

Baxter, M., Terenzini, P. T., \& Hutchings, P. (2002). Learning and teaching in the 21st century: Trends and implications for practice. Retrieved on April 30, 2012, from http://www.acpa.nche.edu/seniorsscholars/trends/trends4.htm

Bonwell, C., \& Eison, J. (1991). Active learning: Creating excitement in the classroom. ERIC Digest (ED340272). Retrieved on December 17, 2013, from http://ericae.net/db/edo/ED340272.htm

Bryson, J., Pajo, K., Ward, R., \& Mallon, M. (2006). Learning at work: Organizational affordances and individual engagement. Journal of Workplace Learning, 18(5), 279-297.

Burgoyne, J. (1988). Competency approaches to management development. Paper presented at the IMP conference, Harrogate.

Butcher, D., Harvey, P., \& Atkinson, S. (1997). Developing business through developing individuals. Research Paper, Cranfield School of Management, Cranfield University.

Cambridge International Dictionary of English (1995). Bath, UK: Bath Press.

Chen, Q., Clifford, S. J., \& Wells, W. D. (2002, April). Attitude toward the site 11 : New information. Journal of Advertising Research, 33-45.

Chickering, A. W., \& Gamson, Z. F. (1987). Seven principles for good practice. AAHE Bulletin, 39, 3-7.

Churchill, G. A. (1979). A paradigm for developing better measures of marketing constructs. Journal of Marketing Research, 16(1), 64-73.

Davis, J. R. (1993). Better teaching, more learning. Strategies for success in post secondary settings. Phoenix, AR: Oryx Press.

Davis, J. R. (1995). Re-engineering teaching for the 21 st century learning. Educational Record, 76(4), $16-22$.

Drucker, P. (1992). Managing for the future. Butterworth-Heinemann.

Dwivedi, Y. K. (2005). Adoption, usage and impact of broadband: UK households (Unpublished doctoral dissertation). Brunel University, UK.

Fishbein, M., \& Ajzen, I. (1975). Belief, attitude, intention and behavior: An introduction to theory and research. Addison-Wesley.

Fogarty, R. (1999). Architects of the intellect. Educational Leadership, 57(3), 76-78.

Fowler, F. J. Jr. (2009). Survey research method. London: Sage Publications.

Fox, E. A. (1997). Examining factors which influence and significantly impact faculty teaching goals. Unpublished Doctoral Dissertation, University of South Carolina. 
Fox-Cardamone, L., \& Rue, S. (2003). Students' responses to active-learning strategies: An examination of small-group and whole-class discussion. Research for Educational Reform, 8, 3-15.

Gardiner, L. F. (1994). Redesigning higher education: Producing dramatic change in student learning. ASHE Report No. 7. Washington, D.C.: Graduate School of Education and Human Development, The George Washington University.

Grasha, A. F. (1996). Teaching with style: A practical guide to enhancing learning by understanding teaching and learning styles. Pittsburgh, PA: Alliance Publishers, (800) 718-4287.

Grubb, W. N., Worthen, H., Byrd, B., Webb, E., Badway, N., Case, C., Groto, S., \& Villenueve, J. C. (1999). Honored but invisible: An inside look at teaching in community colleges. New York: Routledge.

Guskey, T. R. (1994, Fall). Results oriented professional development: In search of an optimal mix of effective practice. Journal of Staff Development, 15(4), 42-50.

Haas, P. P., \& Keeley, S. M. (1998). Coping with faculty resistance to teaching critical thinking. College Teaching, 46(2), 63-67.

Hair, J. F., Black, W. C., Babin, B. J., Anderson, R. E., \& Tatham, R. L. (2006). Multivariate data analysis (6th ed.). New Jersey: Pearson International Edition.

Haldin-Herrgard, T. (2000). Difficulties in diffusion of tacit knowledge in organisations. Journal of Intellectual Capital, 1(4), 357-365.

Hallinger, P., \& Lu, J. (2013). Learner centered higher education in East Asia: Assessing the effect on student engagement. International Journal of Educational Management, 27(6), 594-612.

Halpern, D. F., \& Associates. (1994). Changing college classrooms: New teaching and learning strategies for an increasingly complex world. San Francisco, CA: Jossey-Bass.

Harvey, P., \& Butcher, D. (1998). Those who make a difference: developing businesses through developing individuals. Industrial and Commercial Training, 30(1), 12-15.

Henttonen, K., Kianto, A., \& Ritala, P. (2016). Knowledge sharing and individual work performance: an empirical study of a public sector organization. Journal of Knowledge Management, 20(4), 749-768. http://dx.doi.org/10.1108/JKM-10-2015-0414

Hicks, E., Bagg, R., Doyle, W., \& Young, J. D. (2007). Canadian accountants: Examining workplace learning. Journal of Workplace Learning, 19(2), 61-77.

Jahng, J., Jain, H., \& Ramamurthy, K. (2007). Effects of interaction richness on consumer attitudes and behavioral intentions in e-commerce: some experimental results. European Journal of Information Systems, $16,254-269$.

Kooij, D., de Lange, A., Jansen, P., \& Dikkers, J. (2008). Older workers' motivation to continue to work: five meanings of age. A conceptual review. Journal of Managerial Psychology, 23(4), 364-394.

Korthagen, I., \& Kessels, I. (1999). Linking theory and practice: Changing the pedagogy of teacher education. Educational Researcher, 28(4), 4-17.

Liebowitz, J., \& Beckman, T. (1998). Knowledge organisation: What every manager should know. Boca Raton, FL: CRC Press.

Lohman, M. C. (2000). Environmental inhibitors to informal learning in the workplace: A case study of public school teachers. Adult Education Quarterly, 52(2), 83-101.

Lohman, M. C. (2009). A survey of factors influencing the engagement of information technology professionals in informal workplace learning activities. Information Technology, Learning and Performance Journal, 25(1), 43-52.

Loucks-Horsley, S., Hewson, P. N., Love, N., \& Styles, K. E. (1998). Designing professional development for teachers of science and mathematics. Thousand Oaks, CA: Corwin Press.

Manogran, P., \& Liang, L. S. (1998). Developing a knowledge management system for local government in Malaysia. Paper presented at the national seminar on local government, Kuala Lumpur.

Maurer, T. J., \& Rafuse, N. E. (2001). Learning, not litigating: Managing employee development and avoiding claims of age discrimination. The Academy of Management Executive, 15(4), 110-121. 
McEvoy, G. M., \& Blahna, M. J. (2001). Engagement or disengagement? Older workers and the looming labor shortage. Business Horizons, 44(5), 46-52.

McMillan, S. J., Hwang, J., \& Lee, G. (2003). Effects of structural and perceptual factors on attitudes toward the website. Journal of Advertising Research, 43(4), 400-409.

Meyer, J. P., \& Allen, N. J. (1991). A three-component conceptualization of organizational commitment. Human Resource Management Review, 1(61). https://dx.doi.org/10.1016/1053-4822(91)90011-z

Meyers, C., \& Jones, T. B. (1993). Promoting active learning: Strategies for the college classroom. San Francisco: Jossey-Bass Publishers.

Mintz, J. A. (1999, Spring). Faculty development and teaching: A holistic approach. Academic Search Premiere, 99(85), 32-37.

Mohammed Fathi, N., Eze, U.C., \& Guan, G.G.G (2011). Key determinants of knowledge sharing in an electronics manufacturing firm in Malaysia. Library Review, 60(1), 53-67. http://dx.doi.org/10.1108/00242531111100577

Morgan, G. (1989). Riding the waves of change: Developing managerial competencies for a turbulent world. Jossey-Bass Publishers.

Nonaka, I., \& Takeuchi, H. (1995). The knowledge creating company. New York: Oxford University Press.

O'Banion, T. (1999). A learning college for the 21st century. Phoenix, AZ: Oryx Press.

Pedler, M., Burgoyne, J., \& Boydell, T. (1994). A manager's guide to self-development. London: McGraw-Hill.

Prawat, R. S. (1992). Teachers' beliefs about teaching and learning: A constructivist perspective. American Journal of Education, 100(3), 354-395.

Random House Dictionary of the English Language (1971). New York: Random House.

Saint-Onge, H. (1996, March-April). Tacit knowledge: The key to the strategic alignment of intellectual capital. Strategy and Leadership Journal, 24(2), 10-14.

Sambrook, S., \& Stewart, J. (2000). Factors influencing learning in European leaning oriented organizations: Issues for management. Journal of European Industrial Training, 24(2-4), 209-219.

Schroder, H. (1989). Managerial competence: The key to excellence. New York: Kendall/Hunt Publishing.

Sekaran, U. (2003). Research method for business: A skill building approach (4th ed.). Danvers, MA: John Wiley \& Sons.

Selamat, M. H., \& Choudrie, J. (2007). Using meta-abilities and tacit knowledge for developing learning based systems: A case study approach. The Learning Organization, 14(4), 321-344.

Selamat, M. H., Selladurai, S., \& Abdul Halim, H. M. (2015). The influence of task accomplishment and attitude on active teaching in Malaysian universities. European Journal of Business and Social Science, 4(1), 35-48.

Seldin, P., \& Associates. (1995). Improving college teaching. Bolton, MA: Anker Publishing Co.

Senge, P. M. (1990). The leader's new work: building learning organizations. Sloan Management Review, 32(1), Fall, 7-23.

Shore, L. M., Thornton, G. C., \& Newton, L. A. (1990). Job satisfaction and organizational commitment as predictors of behavioral intentions and employee behaviour. Academy of Management Proceedings, 229-233.

Simon, S. J., \& Peppas, S. C. (2004). An examination of media richness theory in product web site design: An empirical study. Info, 6(4), 270-281.

Stage, F. K., Muller, P. A., Kinzie, J., \& Simmons, A. (1998). Creating learning centered classrooms: What does learning theory have to say? ASHE-ERIC Higher Education Report No. 4. Washington, D.C.: Graduate School of Education and Human Development, The George Washington University.

Sternberg, R. J. (1997). Successful intelligence. New York: Penguin Putnam.

Svinicki, M. D. (Ed.) (1990). The changing face of college teaching. New Directions for Teaching and Learning. 42.

Tangaraja, G., Mohd Rasdi, R., Ismail, M., \& Abu Samah, B. (2015). Fostering knowledge sharing behaviour among public sector managers: a proposed model for the Malaysian public service. Journal of Knowledge Management, 19(1), 121-140. http://dx.doi.org/10.1108/JKM-11-2014-0449 
Tansky, J. W., \& Cohen, D. J. (2001). The relationship between organizational support, employee development, and organizational commitment: An empirical study. Human Resource Development Quarterly, 12(3), 285-300.

Travis, J. E. (1995). Models for improving college teaching: A faculty resource. ASHE-ERIC Higher Education Report No. 6. Washington, DC: Graduate School of Education and Human Development,The George Washington University.

Tsoukas, H. (2002). Do we really understand tacit knowledge? Knowledge Economy and Society Seminar, London.

von Glasersfeld, E. (1987). Learning as a constructive activity. In C. Janvier, Problems of representation in the teaching and learning of mathematics (pp. 3-17). New Jersey: Lawrence Erlbaum Associates, Inc.

Vygotsky, L. S. (1987). Thinking and speech. In R.W. Rieber \& A.S. Carton (Eds.), The collected works of L.S. Vygotsky, Volume 1: Problems of general psychology (pp. 39-285). New York: Plenum Press.

Ward, J., \& Peppard, J. (2002). Strategic planning for information system (3rd ed.). Canada (WP): John Wiley.

Weimer, M. E. (1990). Improving college teaching. San Francisco, CA: JesseyBass.

Weimer, M. E. (1996). Integration of teaching and research: Myth, reality and possibility. In P. Cranton (Ed.), University challenges in faculty work: Fresh perspectives from around the world. San Francisco, CA: JesseyBass.

Weimer, M. E., \& Associates. (1996). Teaching on solid ground: Using scholarship to improve practice. San Francisco, CA: Jossey-Bass.

Weimer, M. E. (2002). Learner-centered teaching: Five key changes to practice. San Francisco, CA: Jossey-Bass.

\section{Copyrights}

Copyright for this article is retained by the author(s), with first publication rights granted to the journal.

This is an open-access article distributed under the terms and conditions of the Creative Commons Attribution license (http://creativecommons.org/licenses/by/4.0/). 